\title{
THE ROLE OF FREQUENCY DOUBLING TECHNOLOGY PERIMETRY IN EARLY DETECTION OF DIABETIC RETINOPATHY
}

\author{
Mario Bradvica ${ }^{1,2}$, Dubravka Biuk ${ }^{1,2}$, Ivanka Štenc Bradvica ${ }^{3,4}$, Maja Vinković ${ }^{1,2}$, \\ Branimir Cerovski ${ }^{5,6}$ and Ivona Barać ${ }^{7}$
}

${ }^{1}$ Department of Ophthalmology, Osijek University Hospital Centre, Osijek, Croatia;

${ }^{2}$ Department of Ophthalmology, Faculty of Medicine, Josip Juraj Strossmayer University of Osijek, Osijek, Croatia;

${ }^{3}$ Department of Neurology, Osijek University Hospital Centre, Osijek, Croatia;

${ }^{4}$ Department of Neurology, Faculty of Medicine, Josip Juraj Strossmayer University of Osijek, Osijek, Croatia;

${ }^{5}$ Department of Ophthalmology, Zagreb University Hospital Centre, Zagreb, Croatia;

${ }^{6}$ Department of Ophthalmology, School of Medicine, University of Zagreb, Zagreb, Croatia;

${ }^{7}$ Osijek University Hospital Centre, Osijek, Croatia

\begin{abstract}
SUMMARY - The aim was to assess whether standard automated perimetry (SAP) and frequency doubling technology (FDT) perimetry are able to detect the effect of diabetes mellitus (DM) on retinal function in DM patients in the early stage of disease and to analyze which method is more specific and sensitive. A randomized cross-sectional study was conducted in three different groups of patients to compare the capability of these two methods to examine visual field and to detect the change in light sensitivity. Visual function was assessed in 60 adults with normal retinal finding, 60 adults with DM without clinically detectable retinopathy and 60 adults with DM and non-proliferative diabetic retinopathy but normal visual acuity. FDT perimetry and SAP were performed in all study patients. The presence and severity of diabetic retinopathy was determined by taking and evaluating two $50^{\circ}$ field color photographs per eye, macula-centered and disc-centered. The following results were obtained by analyzing parameters in the groups of diabetic patients: sensitivity and specificity of SAP and FDT for medium sensitivity 86.7/33.3 ( $\mathrm{p}<0.061)$ and 71.7/41.7 $(\mathrm{p}<0.228)$, respectively; for medium deficit 41.7/76.7 ( $\mathrm{p}<0.063)$ and $65 / 50(\mathrm{p}<0.362)$, respectively; for loss of variance/ pattern standard deviation (LV/PSD) 51.7/61.7 ( $<<0.536)$ and 61.7/51.7 $(\mathrm{p}<0.666)$, respectively; and for foveal sensitivity 81.7/36.7 ( $<<0.096)$ and 23.3/86.7 ( $p<0.839)$, respectively. Analysis of parameters between diabetics and control group yielded sensitivity and specificity for medium sensitivity $71.7 / 61.7$ $(\mathrm{p}<0.001)$ and 70.8/55 ( $<<0.002)$, respectively; for medium deficit 56.7/60 $(\mathrm{p}<0.058)$ and 77.5/43.3 $(\mathrm{p}<0.037)$, respectively; for LV/PSD 58.3/58.3 ( $\mathrm{p}<0.042)$ and 33.3/83.3 $(\mathrm{p}<0.437)$, respectively; and for foveal sensitivity 82.5/53.3 ( $\mathrm{p}<0.001)$ and $28.3 / 85(\mathrm{p}<0.195)$, respectively. We concluded that neither of these methods was sensitive and specific enough to distinguish diabetics without retinopathy from diabetics with retinopathy. Both of these methods were highly specific and sensitive to distinguish diabetics from healthy subjects, but neither of these methods proved superior.
\end{abstract}

Key words: Diabetes mellitus; Diabetic retinopathy; Visual field tests; Photophobia; Visual acuity

\section{Introduction}

Diabetic retinopathy as a complication of diabetes mellitus (DM) is one of the most common causes of vision loss and visual field defects ${ }^{1}$ in developed coun-

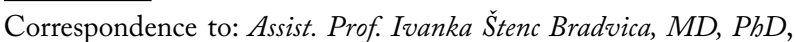
Ružina 140, HR-31000 Osijek, Croatia

E-mail: ivanka.stenc@vip.hr

Received February 28, 2018, accepted July 5, 2018 
tries, as well as in Croatia ${ }^{2}$. Since the duration of DM and chronic hyperglycemia represents a risk factor for developing diabetic retinopathy, advancements in medical care and longer life span have led to an increase in the prevalence of diabetic retinopathy.

Diabetic retinopathy is diagnosed and followed-up by funduscopy with contact or noncontact lenses ( 90 diopters) with regard to the central and peripheral retina $^{3}$. In certain cases, the following diagnostic tests may be supplementary in assessing the extent of diabetic retinopathy: fundus photography and fluorescein angiography, optical coherence tomography (OCT) and ocular ultrasound. Fluorescein angiography helps in assessing the risk of progression from nonproliferative to proliferative form of diabetic retinopathy ${ }^{4-6}$. Color fundus photography is used for detection and documentation of retinal changes and assesses disease progression or response to therapeutic procedures. OCT is very sensitive in detection and follow-up of macular edema ${ }^{7,8}$. OCT provides quantitative information that cannot be obtained by clinical examination or fluorescein angiography, especially in the early stages of diabetic retinopathy. However, it does not provide information about microvascular retinal changes or leakage through the hemato-retinal barrier. Ocular ultrasound detects traction retinal detachment in severe cases of proliferative diabetic retinopathy, especially in cases of opaque optical media (cataract, vitreous hemorrhage $)^{3}$.

Recently, static perimetry has been used in following-up diabetic retinopathy and monitoring functional state of the retina. Araie et al., Werner et al. and Chauhan et al. showed that visual field defect was the most significant marker of visual function ${ }^{9-11}$. Bengtsson et al. and Bengtsson et al. found that visual field changes may be used to detect progression of diabetic retinopathy ${ }^{12,13}$. Recent research projects are trying to find a more appropriate diagnostic method to detect early changes in visual acuity and visual field in order to treat patients more efficiently in the early stages of the disease ${ }^{14}$.

Frequency-doubling technology $(\mathrm{FDT})^{15}$ is used as a screening method to detect early glaucomatous ${ }^{16}$, as well as visual field defects caused by other diseases ${ }^{17}$. Frequency-doubling illusion phenomenon was originally described by Kelly ${ }^{18}$ and has been evaluated later by many other authors ${ }^{19,20}$. FDT is based on the stimuli detected by the retinal ganglion cells with long axons, i.e. magno-cells ( $\mathrm{M}$ cells $)^{21,22}$. Therefore, FDT should be able to detect very early defects in the visual field in contrast to a standard method for detecting visual field defects such as computerized perimetry. It is supposed that computerized perimetry detects visual field changes when already $30 \%$ of $\mathrm{M}$ cells are $\operatorname{lost}^{23,24}$. Additional advantage of FDT over computerized perimetry is shorter duration of the test, which enables us to examine more patients with less discomfort in a short time.

The aim of this study was to determine whether the FDT test results in DM patients are comparable to the results of automated static perimetry; we also wanted to determine the sensitivity and specificity of FDT in detecting early diabetic visual field defects.

\section{Patients and Methods}

A comparative study approved by the regional institutional review board was conducted in the Department of Ophthalmology, Osijek University Hospital Centre in Osijek. A total of 180 subjects were divided into three groups. Group 1 included diabetic patients without clinical signs of diabetic retinopathy; group 2 consisted of diabetic patients with mild diabetic retinopathy according to the Early Treatment Diabetic Retinopathy Study (ETDRS) and American Academy of Ophthalmology (AAO) criteria ${ }^{1}$; group 3 consisted of healthy subjects admitted for blepharoplasty surgery, with normal funduscopy findings, as a control group. All patients were older than 18 years and equally distributed according to age and sex among the groups. If both eyes met the inclusion criteria, only one eye was analyzed by random choice. Exclusion criteria were significant lens opacities according to the Lens Opacities Classification System III (LOCS3) ${ }^{25}$, glaucoma, smokers (more than 10 cigarettes/day), alcoholics (no more than three drinks per day by the National Institute of Alcohol Abuse and Alcoholism, NIAAA) ${ }^{26}$, neurologic and neuro-ophthalmologic disorders that may cause visual field loss.

All patients underwent complete ophthalmologic examination, which included medical history, visual acuity testing on Snellen charts, biomicroscopy, applanation tonometry, funduscopy with a non-contact lens $90 \mathrm{D}$, fundus photography $50^{\circ}$ colors and red free in two fields, macula centered and optical disc centered ${ }^{27}$.

Computerized static perimetry (Octopus 123, Interzeag AG, Schlieren, Switzerland) and frequency- 
doubling perimetry (Frequency Doubling Perimeter, Welch-Allyn, Skaneateles, NY; Zeiss-Humphrey, San Leandro, CA) were used to examine visual fields. Computerized perimetry used the GX1 program with stimuli size Goldman III, 100 millisecond exposition time, 4 apostilb background illumination, maximum stimuli intensity of 1000 apostilbs and 4-2-1 dB method that determines retinal sensitivity with $1 \mathrm{~dB}$ in two phases (32 measurement spots).

The following numerical parameters were analyzed: medium sensitivity (MS), mean defect (MD) and loss of variance (LV) as a mean defect of visual field sensitivity. Foveolar sensitivity was calculated out of those four central values as a mean value. If the reliability factor $(\mathrm{RF})$ was less than $15 \%$, the results were accepted and considered for analysis.

The full threshold test $(\mathrm{N}-20)$ was used on FDT perimetry. It uses 17 measurement points that determine retinal sensitivity with $1 \mathrm{~dB}$ accuracy. The following numerical parameters were analyzed: mean deviation (MD), mean visual field sensitivity loss, and pattern standard deviation (PSD) as localized visual field sensitivity loss that is analogous to LV in computerized perimetry.

Mean sensitivity as the average sensitivity is not automatically calculated, so it was calculated from the so-called threshold diagram (a scheme of numerical value of sensitivity) that represents 17 stimuli thresholds in different retinal locations. A central value on the threshold diagram was used on foveolar sensitivity measurement. The results were considered for analysis if the fixation loss or false negative error was less than $33 \%$ and if the false positive error was less than $15 \%{ }^{27}$.

Total deviation plot diagram was also analyzed and the criteria specific for diabetic retinopathy were determined according to the results of previous studies ${ }^{29}$. According to this diagram, the subjects were divided into 9 groups, as follows: criterion 0: normal finding; criterion 1: one abnormal visual field in any of the tested areas of any intensity; criterion 2: two abnormal visual fields of any intensity which are not one next to each other except for 4; criterion 3: any two fields of abnormal depression one next to other except for 5; criterion 4: one abnormal visual field with central depression or the inner ring except for 5; criterion 5: two abnormal visual fields in the inner ring without central field; criterion 6: central visual field defect; criterion 7: central visual field defect and minimally two fields in the inner ring; and criterion 8: $\geq 3$ abnormal visual fields except for 7 .

Such stratification of the results aimed to determine if the visual field defects had sufficient specificity and sensitivity to detect early diabetic retinopathy changes. At each visit, both perimetry tests were performed. The first test was selected by random choice. The time interval between two perimetry tests was at least 30 minutes and in that time ophthalmologic examination was performed. The tests were taken by a perimetry technician blinded to the patient group.

\section{Statistics}

Kolmogorov-Smirnov test was used to evaluate the normality of distribution of numerical variables. Mann Whitney test was used to determine differences between two independent groups within one measurement. Differences among three or more groups were demonstrated by Kruskal-Wallis test. $\chi^{2}$-test was used to test differences between categorical variables. Wilcoxon test for nonparametric distribution was used to test differences between two dependent samples. Correlation between specific parameters was tested by Spearman's correlation coefficient. ROC analysis tested optimal boundary values, area under ROC curve, specificity and sensitivity of the tested variables as a diagnostic method in differentiating retinopathy in diabetics. The $p$ value of 0.05 was chosen to determine the significance of the results. The analyses were performed using commercially available Statistics for Windows 2005 software (version 7.1, StatSoft Inc., Tulsa, OK, USA).

\section{Results}

In this study, we evaluated 180 subjects divided into three groups. Group 1 consisted of diabetic patients without clinical signs of diabetic retinopathy, group 2 included diabetic patients with mild diabetic retinopathy, and group 3 were healthy controls. There were 80 (44.4\%) men and 100 (55.6\%) women, equally distributed among groups $(\mathrm{p}=0.978)$. There was no age difference among the three groups of subjects $(\mathrm{p}=0.128)$.

Tested spots were successively labeled as VP1, VP2, etc. for computerized perimetry and FDTM1, FDTM2, etc. for FDT perimetry, starting from the 
superior nasal part towards the inferior temporal part. The mean value of every single spot was obtained for each group of subjects and the results were analyzed to determine if there was a significant difference among different areas of visual field. Computerized perimetry yielded a statistically significant difference between diabetics with retinopathy and control group of healthy subjects ( $\mathrm{p}<0.05$ in 29 out of 32 measured points), whereas there was no significant difference in the loss of retinal sensitivity between the groups of diabetics with and without retinopathy $(\mathrm{p}<0.05$ in 10 out of 32 measured points).

Analysis of FDT perimetry results showed a statistically significant difference between diabetics with retinopathy and control group of subjects $(p<0.05$ in 12 out of 17 measured points), whereas there was no significant difference in the loss of retinal sensitivity between the groups of diabetics with and without retinopathy ( $\mathrm{p}<0.05$ in 5 out of 17 measured points).

Comparative analysis of the parameters measured by computerized perimetry and FDT was performed. Medium sensitivity, mean defect and loss of variance were analyzed by computerized perimetry. The average central sensitivity of visual field, which was used for comparison, was calculated from the four central values of visual field.

The following parameters were analyzed in FDT: mean deviation, PSD, foveolar sensitivity and mean sensitivity of visual field. The latter parameter was calculated by arithmetic mean of the sensitivity of 17 measured spots in the visual field.

In the group of diabetics without retinopathy, there was a significantly higher loss of variance measured by computerized perimetry (4.9, interquartile range 3.19.2) as opposed to 3.9 median measured with FDT. Diabetics with retinopathy had a significantly lower loss of variance measured by computerized perimetry (5.6, interquartile range 2.8-9.1) than the loss of variance measured by FDT (4.1, interquartile range 3.1-4.9).

In control group, the mean sensitivity was significantly higher, whereas the mean central value was lower when measured by FDT. The mean sensitivity was significantly different across the three groups of patients on both diagnostic tests, i.e. computerized perimetry and FDT. The MS parameter was significantly different across the three groups of patients in both visual field tests, whereas MD was different when using computerized perimetry, while FDT did not detect significant difference among the three study groups.
Table 1. Differences in study parameters across the three groups of subjects

\begin{tabular}{|c|c|c|}
\hline \multirow{3}{*}{ Parameter } & \multicolumn{2}{|c|}{ Diagnostic procedure } \\
\hline & $\mathrm{CP}$ & FDP \\
\hline & $\mathrm{p}^{*}$ & $\mathrm{p}^{*}$ \\
\hline \multicolumn{3}{|l|}{ Mean sensitivity } \\
\hline $\begin{array}{l}\text { Diabetics without } \\
\text { vs. with retinopathy }\end{array}$ & 0.066 & 0.232 \\
\hline $\begin{array}{l}\text { Diabetics without retinopathy } \\
\text { vs. control group }\end{array}$ & 0.003 & 0.031 \\
\hline $\begin{array}{l}\text { Diabetics with retinopathy } \\
\text { vs. control group }\end{array}$ & $<0.001$ & 0.002 \\
\hline All diabetics vs. control group & $<0.001$ & 0.002 \\
\hline \multicolumn{3}{|l|}{ Mean deficiency } \\
\hline $\begin{array}{l}\text { Diabetics without } \\
\text { vs. with retinopathy }\end{array}$ & 0.069 & 0.365 \\
\hline $\begin{array}{l}\text { Diabetics without retinopathy } \\
\text { vs. control group }\end{array}$ & 0.436 & 0.148 \\
\hline $\begin{array}{l}\text { Diabetics with retinopathy } \\
\text { vs. control group }\end{array}$ & 0.017 & 0.031 \\
\hline All diabetics vs. control group & 0.067 & 0.037 \\
\hline \multicolumn{3}{|l|}{ LV/PSD } \\
\hline $\begin{array}{l}\text { Diabetics without } \\
v s . \text { with retinopathy }\end{array}$ & 0.537 & 0.667 \\
\hline $\begin{array}{l}\text { Diabetics without retinopathy } \\
\text { vs. control group }\end{array}$ & 0.145 & 0.493 \\
\hline $\begin{array}{l}\text { Diabetics with retinopathy } \\
\text { vs. control group }\end{array}$ & 0.055 & 0.519 \\
\hline All diabetics vs. control group & 0.051 & 0.442 \\
\hline \multicolumn{3}{|l|}{ Medium central sensitivity } \\
\hline $\begin{array}{l}\text { Diabetics without } \\
\text { vs. with retinopathy }\end{array}$ & 0.102 & 0.839 \\
\hline $\begin{array}{l}\text { Diabetics without retinopathy } \\
\text { vs. control group }\end{array}$ & 0.003 & 0.307 \\
\hline $\begin{array}{l}\text { Diabetics with retinopathy } \\
\text { vs. control group }\end{array}$ & $<0.001$ & 0.214 \\
\hline All diabetics vs. control group & $<0.001$ & 0.190 \\
\hline
\end{tabular}

$\mathrm{CP}=$ computerized perimetry; FDP = frequency doubling perimetry; $\mathrm{LV}=$ loss of variance; $\mathrm{PSD}=$ pattern standard deviation; *Mann Whitney test

Computerized perimetry detected significant MS difference between diabetics without and with retinopathy as compared to control group of healthy subjects. A significantly greater diffuse loss of visual field was measured in diabetics with retinopathy as compared to control group (Table 1). 
Table 2. Parameters of the receiver operating characteristic (ROC) curve in diabetics versus control group

\begin{tabular}{|c|c|c|c|c|c|c|}
\hline Parameter & AUC & $95 \% \mathrm{CI}$ & Sensitivity & Specificity & Cut off & $\mathrm{p}$ \\
\hline \multicolumn{7}{|c|}{ Mean sensitivity } \\
\hline $\mathrm{CP}$ & 0.708 & $0.636-0.773$ & 71.7 & 61.7 & $\leq 28.6$ & $<0.001$ \\
\hline FDP & 0.639 & $0.565-0.710$ & 70.8 & 55 & $\leq 29.8$ & 0.002 \\
\hline \multicolumn{7}{|c|}{ Mean deficiency } \\
\hline $\mathrm{CP}$ & 0.584 & $0.508-0.657$ & 56.7 & 60 & $>-0.6$ & 0.058 \\
\hline FDP & 0.594 & $0.520-0.668$ & 77.5 & 43.3 & $\leq 0.82$ & 0.037 \\
\hline \multicolumn{7}{|l|}{ LV/PSD } \\
\hline $\mathrm{CP}$ & 0.589 & $0.514-0.662$ & 58.3 & 58.3 & $>4.6$ & 0.042 \\
\hline FDP & 0.535 & $0.460-0.610$ & 33.3 & 83.3 & $>4.5$ & 0.437 \\
\hline \multicolumn{7}{|c|}{ Medium central sensitivity } \\
\hline $\mathrm{CP}$ & 0.694 & $0.621-0.760$ & 82.5 & 53.3 & $\leq 32.5$ & $<0.001$ \\
\hline FDP & 0.560 & $0.484-0.633$ & 28.3 & 85.0 & $\leq 27$ & 0.195 \\
\hline
\end{tabular}

$\mathrm{AUC}=$ area under the curve; $95 \% \mathrm{CI}=95 \%$ confidence interval; $\mathrm{CP}=$ computerized perimetry; $\mathrm{FDP}=$ frequency doubling perimetry; $\mathrm{LV}$ $=$ loss of variance; $\mathrm{PSD}=$ pattern standard deviation

Thirty-eight (21.1\%) subjects had normal visual field, equally in all study groups. One abnormal visual field anywhere in the tested range was presented in 33 (18.3\%) subjects, a little less pronounced in diabetics without retinopathy but not statistically significant. Eleven (6.1\%) subjects had two fields of abnormal depression one next to other and only five (8.3\%) control group subjects had one abnormal visual field in the center or inner ring.

Seventy-seven (42.8\%) subjects had three or more abnormal fields except for criterion 7 . The majority $(\mathrm{n}=30 ; 50 \%)$ were patients from diabetic groups and 17 (18.3\%) from control group. Results of both perimetry tests in diabetic groups could not identify the specific parameter that would identify retinopathy in the visual field of these patients.

The MS parameter differentiated diabetics from the control group significantly on both perimetry tests $(\mathrm{p}=0.002)$. The MD parameter tested with FDT helped distinguish diabetics from the control group of subjects. The LV parameter differentiated diabetics from control subjects on computerized perimetry, whereas PSD measured with FDT did not show significant difference among the three groups of patients. The threshold central value measured with computerized perimetry could distinguish diabetics from the control group, whereas FDT did not differentiate these groups of subjects (Table 2).

\section{Discussion}

Diabetic retinopathy is a significant socio-medical issue since it affects a large proportion of working population. Diagnosis and follow-up of this clinical entity is predominantly based on fundus examination, which has been standardized by the ETDRS study ${ }^{4}$, and visual acuity testing as visual function evaluation. In recent time, visual field testing is introduced since it represents functional equivalent of retinal tissue damage and may be used to show the progression and development of diabetic retinopathy. It has been speculated that it may detect signs of functional defects before clinically evident signs of diabetic retinopathy ${ }^{30}$. Different visual field tests have been evaluated and SAP has been shown to be more reliable and reproducible than standard white on white perimetry and blue on yellow perimetry (short wavelength perimetry) ${ }^{13,31}$. It is the gold standard for detecting focal retinal defects and glaucomatous defects. FDT visual field testing was developed 15 years ago and it could detect earlier defects in visual field in glaucoma patients ${ }^{28}$. We hypothesized that it might detect early functional changes in diabetic retinopathy, so we compared it to computerized perimetry. We compared mean values of each tested spot between FDT and computerized perimetry. Computerized perimetry yielded significant differences among the three study groups in most of 
the spots tested (28 out of 32). The most significant difference was observed when comparing diabetics with diabetic retinopathy and control group (29 out of 32 ), confirming the presumption that clinically detectable retinal changes would result in functional defects, which is also in accordance with literature data ${ }^{32,33}$. It was expected because the normal population had no visual field loss, whereas the patients with clinically detectable retinal changes had a substantial visual field loss ${ }^{31,32}$, which may signify underlying neuropathy ${ }^{31,34-36}$, and may be the cause of focal visual field loss in cases of normal funduscopy findings.

Testing by FDT perimetry showed a slight statistically significant difference across the three groups of subjects ( 8 out of 17). The most prominent differences were observed between diabetics with retinopathy and control group of patients (12 out of 17) and between diabetics with retinopathy and diabetics with normal retinal finding (1 out of 17), reflecting visual field defects in specific groups of patients (patients with pathologic changes on funduscopy had greater visual field loss than healthy subjects). This was also recorded in computerized perimetry although the FDT test had fewer significantly different results than the computer perimetry test, which in this sense made it a less sensitive method.

Jackson et al..$^{37}$ demonstrated better discrimination of foveolar sensitivity among diabetics without retinopathy, diabetics with retinopathy and control group of patients $(p<0.0001)$ when testing with Matrix perimetry as compared with our study $(p=0.415)$. Matrix perimetry is a new generation FDT with more testing spots $\left(n=55,5^{\circ} \times 5^{\circ}\right)$ compared to FDT test used in the present study $\left(17\right.$ test spots $\left.10^{\circ} \times 10^{\circ}\right)$. The study by Jackson et al. included patients with advanced stages of diabetic retinopathy and best corrected visual acuity (BCVA) 0.8 (Snellen), whereas we included mild diabetic retinopathy and BCVA 1.0 (Snellen), so it could explain the more pronounced difference and statistically significant result. The mean sensitivity loss was observed in diabetics with retinopathy and control group, which is in concordance with our results but they did not find significant difference between diabetics without retinopathy and control group. The mean sensitivity loss measured by Matrix perimetry did not significantly differ between diabetics without retinopathy and control group, whereas our results showed significant difference between these two groups as well $(\mathrm{p}=0.031)$. According to Jackson et al. ${ }^{37}$, SAP testing yielded no significant difference among different groups for mean foveolar sensitivity, whereas our results showed significant differences $(p<0.001)$. The mean sensitivity was statistically different across the observed groups in both studies.

In the study by Parravano et al..$^{38}$, a group of diabetics without retinopathy and control group of healthy subjects were tested with SAP and Matrix FDT perimeter. They showed significant differences in $\mathrm{MD}$ and no significant change in PSD with Matrix perimetry test. Our results reflected similar findings since we did not find significant difference in MD and PSD either. Using computerized perimetry, they found significant difference in MD and PSD, whereas we recorded no significant difference in these two parameters. According to these authors, they found a difference in MD between the two groups by using Matrix perimetry and SAP testing revealed significant changes in both MD and PSD. Our study showed significant difference between diabetics without retinopathy and healthy control group in the mean sensitivity by both methods and in the mean central sensitivity only by computerized perimetry. It may be concluded that computerized perimetry has advantage over FDT in testing diabetic visual field loss.

In the work by Realini et al..$^{39}$, FDT was used in screening of glaucoma and they concluded that diabetes might be the cause of false positive finding, whereas Khandekar et al. in a similar study showed that diabetes did not influence the results of FDT test in glaucoma patients ${ }^{40}$. We confirmed that DM might influence the results of the FDT perimetry test.

We further tried to establish if there was a pathognomonic defect sample that would be characteristic of diabetic visual field loss, as suggested by previous results $^{29}$. The only difference observed among the three groups was criterion 5 , i.e. one abnormal central field or the inner ring field $\left(\chi^{2}\right.$-test: $\left.\mathrm{p}=0.006\right)$ and criterion 8 , i.e. three or more abnormal fields $\left(\chi^{2}\right.$-test: $\left.\mathrm{p}=0.022\right)$. Five patients in the control group and none in the diabetic group of patients had visual field loss as in criterion 5. Diabetic patients had a more pronounced visual field loss and a significant difference was detected in the control group. Criterion 8 was significantly different in all three groups of patients but this criterion encompasses many different patterns of visual 
field loss, so it cannot represent the standardized pattern.

Cross analysis of normal and pathologic visual field findings did not detect specific pattern of diabetic visual field loss, confirming the results reported by Parravano et al..$^{38}$. However, some authors showed high specificity and sensitivity in particular visual field samples ${ }^{29}$.

The receiver operating characteristic (ROC) curve analyzed specificity and sensitivity of both FDT and computerized perimetry in the group of diabetic patients with and without retinopathy and control group. In both diabetic patient groups, none of the tests differentiated the presence of retinopathy. However, both visual field tests differentiated diabetics from the control group of patients: SAP $(\mathrm{p}<0.001)$ and FDT $(\mathrm{p}=0.002)$. The MD parameter differed between diabetics and control group $(\mathrm{p}=0.037)$ when tested with FDT. SAP significantly differentiated loss of variance $(\mathrm{p}=0.042)$ and foveolar sensitivity $(\mathrm{p}<0.001)$ in diabetics compared to control group. FDT and computerized perimetry cannot differentiate diabetics without retinopathy from diabetics with retinopathy with sufficient specificity and sensitivity but may differentiate diabetics from healthy control group of subjects. However, none of the tests showed superiority to the other.

\section{Conclusion}

Based on our data analyses, we can conclude that FDT may differentiate healthy subjects from diabetic patients equally as computerized perimetry. It does not discriminate well diabetics without retinopathy from diabetics with mild retinopathy, which, according to the results of our study, cannot be achieved with computerized perimetry either. It is a test that is less time consuming than computerized perimetry, thus being more convenient for the patient.

We could not establish specific pattern of visual field loss that is pathognomonic for diabetic retinopathy. FDT detected and differentiated diabetic patients from healthy control subjects with $70.8 \%$ sensitivity and $55.0 \%$ specificity for MS and $77.5 \%$ sensitivity and $43.3 \%$ specificity for MD. Therefore, we think that this test may be a useful tool in combination with other clinical methods for evaluation of diabetic visual field loss. Neither of the methods could discriminate well diabetics without retinopathy from diabetics with retinopathy but both tests might differentiate diabetics from healthy controls with sufficient sensitivity and specificity for MS parameter. In addition, it could not be confirmed that either method showed advantage over the other.

\section{References}

1. Tomic M, Vrabec R, Poljicanin T, Ljubic S, Duvnjak L. Diabetic macular edema: traditional and novel treatment. Acta Clin Croat. 2017;56(1):124-32. doi: 10.20471/acc.2017.56.01.18

2. Galetović D, Olujić I, Znaor L, Bućan K, Karlica D, Lesin M, Susac T. The role of diabetic retinopathy in blindness and poor sight in Split-Dalmatia County 2000-2010. Acta Clin Croat. 2013 Dec;52(4):448-52.

3. American Academy of Ophthalmology. Diabetic retinopathy Preferred Practice Pattern. 2019 Available from: www.aao.org/ ppp

4. Early Treatment Diabetic Retinopathy Study Research Group. Classification of diabetic retinopathy from fluorescein angiograms. ETDRS report number 11. Ophthalmology. 1991;98 (5 Suppl):807-22

5. Early Treatment Diabetic Retinopathy Study Research Group. Fluorescein angiographic risk factors for progression of diabetic retinopathy. ETDRS report number 13. Ophthalmology. 1991;98(5 Suppl):834-40.

6. Early Treatment Diabetic Retinopathy Study Research Group. Focal photocoagulation treatment of diabetic macular edema. Relationship of treatment effect to fluorescein angiographic and other retinal characteristics at baseline: ETDRS report no. 19. Arch Ophthalmol. 1995;113(9):1144-55.

7. Kim BY, Smith SD, Kaiser PK. Optical coherence tomographic patterns of diabetic macular edema. Am J Ophthalmol. 2006; 142(3):405-12. doi: 10.1016/j.ajo.2006.04.023

8. Massin P, Girach A, Erginay A, Gaudric A. Optical coherence tomography: a key to the future management of patients with diabetic macular oedema. Acta Ophthalmol Scand. 2006;84 (4):466-74. doi: 10.1111/j.1600-0420.2006.00694.x

9. Araie M, Yamagami J, Suziki Y. Visual field defects in normaltension and high-tension glaucoma. Ophthalmology. 1993;100 (12):1808-14.

10. Werner EB, Krupin T, Adelson A, Feitl ME. Effect of patient experience on the results of automated perimetry in glaucoma suspect patients. Ophthalmology. 1990;97(1):44-8.

11. Chauhan BC, Drance SM, Douglas GR. The use of visual field indices in detecting changes in the visual field in glaucoma. Invest Ophthalmol Vis Sci. 1990;31(3):512-20.

12. Bengtsson B, Heijl A, Agardh E. Visual fields correlate better than visual acuity to severity of diabetic retinopathy. Diabetologia. 2005;48(12):2494-500. doi: 10.1007/s00125-005-0001-x

13. Bengtsson B, Hellgren KJ, Agardh E. Test-retest variability for standard automated perimetry and short-wavelength automat- 
ed perimetry in diabetic patients. Acta Ophthalmol. 2008; 86(2):170-6. doi: 10.1111/j.1600-0420.2007.01019.x

14. Landers J, Goldberg I, Graham S. A comparison of short wavelength automated perimetry with frequency doubling perimetry for the early detection of visual field loss in ocular hypertension. Clin Experiment Ophthalmol. 2000;28(4):248-52.

15. Cerovski B. Suvremene perimetrijske strategije i glaukom. Ophthalmol Croat. 2002;11(1-4):27-34. (in Croatian)

16. Takahashi G, Demirel S, Johnson CA. Predicting conversion to glaucoma using standard automated perimetry and frequency doubling technology. Graefes Arch Clin Exp Ophthalmol. 2017;255(4):797-803. doi: 10.1007/s00417-016-3573-x

17. Tanga L, Centofanti M, Oddone F, Parravano M, Parisi V, Ziccardi L, et al. Retinal functional changes measured by frequency-doubling technology in patients treated with hydroxychloroquine. Graefes Arch Clin Exp Ophthalmol. 2011;249 (5):715-21. doi: 10.1007/s00417-010-1612-6

18. Kelly DH. Nonlinear visual responses to flickering sinusoidal gratings. J Opt Soc Am. 1981;71(9):1051-5.

19. Richards W, Felton TB. Spatial frequency doubling: retinal or central. Vision Res. 1974;13:1229-37.

20. Tyler CW. Observations on spatial-frequency doubling. Perception. 1974;3(1):81-6.

21. Johnson CA, Demirel S. The role of spatial and temporal factors in frequency-doubling perimetry. In: Wall MH, editor. International Perimetric Society Meeting. Amsterdam/New York: Kugler; 1996. p. 13-9.

22. Burnstein Y, Ellish NJ, Magbalon M, Higginbotham EJ. Comparison of frequency doubling perimetry with Humphrey visual field analysis in a glaucoma practice. Am J Ophthalmol. 2000;129(3):328-33. doi: S0002939499003645

23. Pederson JE, Anderson DR. The mode of progressive disc cupping in ocular hypertension and glaucoma. Arch Ophthalmol. 1980;98(3):490-5.

24. Quigley HA, Addicks EM, Green WR. Optic nerve damage in human glaucoma. III. Quantitative correlation of nerve fiber loss and visual field defect in glaucoma, ischemic neuropathy, papilledema, and toxic neuropathy. Arch Ophthalmol. 1982; 100(1):135-46.

25. Thylefors B, Chylack LT Jr, Konyama K, Sasaki K, Sperduto R, Taylor HR, et al. A simplified cataract grading system. Ophthalmic Epidemiol. 2002;9(2):83-95.

26. de Carvalho JF, Danda D, Dantas H, Arraes TA, Cavalcanti E. [Blue-on-yellow perimetry in tobacco and alcohol consumers]. Arq Bras Oftalmol. 2006;69(5):675-8. doi: S0004-27492006 000500010 (in Portuguese)

27. Saari JM, Summanen P, Kivela T, Saari KM. Sensitivity and specificity of digital retinal images in grading diabetic retinopathy. Acta Ophthalmol Scand. 2004;82(2):126-30. doi: 10.1111 /j.1600-0420.2004.00240.x
28. Liu S, Lam S, Weinreb RN, Ye C, Cheung CY, Lai G, et al. Comparison of standard automated perimetry, frequency-doubling technology perimetry, and short-wavelength automated perimetry for detection of glaucoma. Invest Ophthalmol Vis Sci. 2011;52(10):7325-31. doi: 10.1167/iovs.11-7795

29. Parikh R, Naik M, Mathai A, Kuriakose T, Muliyil J, Thomas $\mathrm{R}$. Role of frequency doubling technology perimetry in screening of diabetic retinopathy. Indian J Ophthalmol. 2006;54 (1):17-22.

30. Pahor D. [Reduction of retinal light sensitivity in diabetic patients]. Klin Monbl Augenheilkd. 2003;220(12):868-72. doi: 10.1055/s-2003-812556 (in German)

31. Jackson GR, Barber AJ. Visual dysfunction associated with diabetic retinopathy. Curr Diab Rep. 2010;10(5):380-4. doi: 10.1007/s11892-010-0132-4

32. Pahor D. Automated static perimetry as a screening method for evaluation of retinal perfusion in diabetic retinopathy. Int Ophthalmol. 1997;21(6):305-9.

33. Curtis TM, Gardiner TA, Stitt AW. Microvascular lesions of diabetic retinopathy: clues towards understanding pathogenesis? Eye (Lond). 2009;23(7):1496-508. doi: 10.1038/eye. 2009.108

34. Bek T. Localized retinal morphology and differential light sensitivity in diabetic retinopathy. Methodology and clinical results. Acta Ophthalmol Suppl. 1992;207:1-36.

35. Barber AJ, Gardner TW, Abcouwer SF. The significance of vascular and neural apoptosis to the pathology of diabetic retinopathy. Invest Ophthalmol Vis Sci. 2011;52(2):1156-63. doi: 10.1167/iovs.10-6293

36. Gardner TW, Abcouwer SF, Barber AJ, Jackson GR. An integrated approach to diabetic retinopathy research. Arch Ophthalmol. 2011;129(2):230-5. doi: 10.1001/archophthalmol. 2010.362

37. Jackson GR, Scott IU, Quillen DA, Walter LE, Gardner TW. Inner retinal visual dysfunction is a sensitive marker of nonproliferative diabetic retinopathy. Br J Ophthalmol. 2012;96 (5):699-703. doi: 10.1136/bjophthalmol-2011-300467

38. Parravano M, Oddone F, Mineo D, Centofanti M, Borboni P, Lauro R, et al. The role of Humphrey Matrix testing in the early diagnosis of retinopathy in type 1 diabetes. $\mathrm{Br} \mathrm{J}$ Ophthalmol. 2008;92(12):1656-60. doi: 10.1136/bjo.2008.143057

39. Realini T, Lai MQ, Barber L. Impact of diabetes on glaucoma screening using frequency-doubling perimetry. Ophthalmology. 2004;111(11):2133-6. doi: 10.1016/j.ophtha.2004.05.024

40. Khandekar R, Zutshi R, Ali M, Raisi AA, Dass H. Influence of diabetes on the validity glaucoma screening by frequency doubling perimetry: a hospital-based study in Oman. Diabetes Technol Ther. 2008;10(4):278-82. doi: 10.1089/dia.2007.0272 
Sažetak

\title{
ULOGA FDT PERIMETRIJE U RANOM OTKRIVANJU DIJABETIČKE RETINOPATIJE
}

\author{
M. Bradvica, D. Biuk, I. Štenc Bradvica, M. Vinković, B. Cerovski i I. Barać
}

Cilj rada bio je utvrditi mogu li standardna automatizirana perimetrija (SAP) i perimetrija udvostručene frekvencije (frequency doubling technology, FDT) otkriti učinke dijabetesa na funkciju retine u osoba s dijabetesom u ranoj fazi bolesti i ocijeniti koja je metoda bolja, jer se dosadašnji radovi spore oko činjenice može li FDT otkriti funkcionalne promjene u bolesnika s dijabetesom prije SAP-a. Svim ispitanicima koji su zadovoljili uključne kriterije testirano je vidno polje pomoću SAP-a i FDT perimetrije. Dobiveni parametri statistički su obrađeni i doneseni su zaključci o valjanosti otkrivanja oštećenja vidnog polja upotrebom svakog od testova. Vidna funkcija istražena je u tri skupine od po 60 ispitanika. Prvu skupinu činili su zdravi ispitanici, drugu bolesnici s dijabetesom bez klinički vidljive dijabetičke retinopatije, a treću skupinu bolesnici s dijabetesom i klinički vidljivom početnom neproliferacijskom dijabetičkom retinopatijom. Postojanje dijabetičke retinopatije utvrđeno je analizom dviju fotografija očne pozadine širine $50^{\circ}$, jedna s centrom u makuli i druga s centrom na papili vidnoga živca. Analizirajući parametre među skupinama dijabetičara nađena je osjetljivost i specifičnost SAP-a i FDT-a za srednju osjetljivost (SO) 86,7/33,3 (p<0,061) i 71,7/41,7 ( $<<0,228$ ), za srednji deficit (SD) 41,7/76,7 ( $<<0,063$ ) i 65/50 ( $<<0,362$ ), za loss of variance/pattern standard deviation (LV/PSD) 51,7/61,7 ( $<<0,536)$ i 61,7/51,7 ( $<<0,666)$ te za foveolarnu osjetljivost $81,7 / 36,7(\mathrm{p}<0,096)$ i 23,3/86,7 ( $<<0,839)$. Analizirajući parametre između skupina dijabetičara i kontrolne skupine zdravih ispitanika nađeni su sljedeći podatci: osjetljivost i specifičnost SAP-a i FDT-a za SO 71,7/61,7 (p<0,001) i 70,8/55 (p<0,002), za SD 56,7/60 (p<0,058) i 77,5/43,3 (p<0,037), za LV/PSD 58,3/58,3 ( $<<0,042)$ i 33,3/83,3 (p<0,437) te za foveolarnu osjetljivost 82,5/53,3 ( $\mathrm{p}<0,001$ ) i $28,3 / 85$ ( $\mathrm{p}<0,195)$. Zaključak je bio da nijedna od navedenih metoda ne može primjereno razlučiti dijabetičare bez retinopatije od dijabetičara s retinopatijom, ali obje metode s razumnom osjetljivošću i specifičnošću razlikuju dijabetičare od zdravih ispitanika prema parametru SO. Također nije bilo moguće potvrditi da je jedna metoda značajno bolja od druge.

Ključne riječi: Dijabetes melitus; Dijabetična retinopatija; Vidno polje, testovi; Fotofobija; Vidna oštrina 